\title{
ESTIMATION OF THE CRITICAL PERIOD FOR WEED CONTROL IN SOYBEAN (Glycine max L) AS INFLUENCED BY PLANT DENSITY \\ El-Gizawy, N. Kh. B. ${ }^{1}$; \\ I. E. Soliman ${ }^{2}$ \\ 1- Faculty of Agriculture at Moshtohor, Benha University. \\ 2- Weed Research Central Laboratory, Agric. Res. Center, Giza, Egypt.
}

\begin{abstract}
Two field experiments were carried out at in clay soil in Agricultural Research and Experimental Center of Agriculture at Faculty of Moshtohor, Benha University, Kalubia Governorate during 2009 \& 2010 summer seasons to determine the critical period of weed competition between weeds and soybean crop through use of regression and economic approaches and also determine the relationship between weeds and soybean yield under three plant densities (105, 140 and 175 thousand plant/ fad.) and ten treatments in two types of treatments (in the first type soybean was hand weeded for different periods 3, 6, 9 and 12 weeks after sowing (W.A.S.) and for whole season, then no further weeding was done while, in the second type weeds were allowed to grow for different periods at 3, 6, 9 (W.A.S.) until harvest the weeds were removed by hand- weeded and weed competition treatment for whole season on seed yield of soybean and associated weeds.

The main results showed that, maximum yield losses of soybean due to weed competition in the whole season were 37.6 and $34.4 \%$ from weed free treatments in 2009 and 2010 seasons. Mathematical model for the relationship between weed free and weed competition periods according to the recommended losing yield value (10), clear that critical period of weed competition under 105 thousand plants density/fad., were (6.5 and 7.0) weeks for weed free as well as $(4.25$ and 4.25) for weed competition in 2009 and 2010 seasons, respectively. Under 140 thousand plant density the respective values were (6.2 and 6.3) weeks for weed free as well as (3.9 and 4.2) for weed competition and for 175 thousand plant density were (5.9 and 5.6) weeks for weed free as well as (3.5 and4.15) weeks for weed competition in 2009 and 2010 seasons, respectively. The critical period of weed treatments over plant densities were $(6.45$ and 6.4) weeks for weed free as well as (4.9 and 4.65) weeks for weed competition in 2009 and 2010 seasons, respectively. All weed competition exerted significant efficiency in controlling annual weeds. Weed free for the whole season treatment gave the best control for annual weeds gave the highest values of yield and yield components in two seasons. The sowing 175000 plant/fad. gave the lowest weight for dry weight for annual weeds and the tallest plants in first and second seasons. 105000 plant/fad., gave the best values of No. of branches and seed weight/plant in the first and second seasons. 140000 plant/fad., gave the highest value of No. of seed pod, weight of 100 seed and yield ton/fad. in the two seasons. Plots weeded at 3 and 6 week after sowing showed the best performance in all aspects of soybean. Such knowledge should be disseminated to farmers to keep soybean yield losses of weed competition to maintain maximum soybean seed yield. This study showed that negative correlation for annual weed weight and all studied characters under study.
\end{abstract}

Keywords: Weed infestation - Plant density - Hoeing -Critical period. 


\section{INTRODUCTION}

Soybean (Glycine max L.) is the most important oil seeds and grain legume crop in the world, so special attention should be directed towards the proper choice of management practices to increase both seed yield and oil production. Successful weed control is one of the most important practices for economical soybean production. Losses due to weeds have been one of the major limiting factors in soybean production, where, weeds compete with soybean for light, moisture and nutrients with early- season competition, being the most critical. Knowledge about the critical period of competition and the magnitude of yield losses due to competition is the key for integrated weed management in soybean to determine the periods in which should handing of the use of pre-emergence or post emergence herbicides should be applied in this period to avoid yield losses in soybean. The time of weed removal from soybean was as important as the extent of removal. Interference up 4 weeks after soybean emergence did not reduce soybean yield as long as moisture was adequate (Jackson et al., (1985). The critical period has been defined as the period during which weeds much controlled to prevent yield losses. It has been used to determine the period when control operation should be carried out to minimize yield losses for many crops (Zimdahl 1988). Odeleye et al., (2007) found that, plots left unweeded inevitably had the highest yield reduction in both varieties. On the other hand, plots weeded at 2 and 6 week after sowing showed the best performance in all aspects for both varieties of soybean. The effect of weed free treatments were significant on yield and pod number per plant while seed number in pod and 100 -seed weights of soybean were not significantly affected by Moghadam et al., (2010). The growth, yield parameters and yield of soybean increased when the plots were maintained weed free conditions up to 30 and 40 days after sowing. Maintaining weed free conditions beyond 40 days after sowing did not prove beneficial in case of soybean. Similarly, weed infestation before 30 day after sowing has no significant adverse effect on soybean crop. The results clearly indicate that critical period of crop weed competition in soybean lies between 30-40 days after sowing (Nagaraju and Kumar 2009 and Chirila and Chirila 2008). It has been demonstrated that usually this crop is more sensitive to the weediness between the periods of 20-35 after emergence days. If the weeds emerge earlier to the crop, weed harmfulness competition start earlier. Soybean yield was significantly affected by its densities and the yield increased as density increased up to $40 \mathrm{plants} / \mathrm{m}^{2}$ (Raei et al., 2008). Weed control should be carried out between 26-63 day after soybean planting to provide maximum grain yield (Keramati et al., 2008). Weeds are one of the major determents in sustaining soybean productivity. The first 15-45 days of crop growth is very critical for weed competition (Yaduraju and Mishra 2004). Thus, the purpose of this study was trying to through lights about the critical period of weed control in soybean as affected by plant density. 


\section{MATERIALS AND METHODS}

Two field experiments were carried out during $2009 \& 2010$ summer seasons in the Agricultural Research and Experimental Center of Agriculture at Faculty of Moshtohor, Benha University, Kalubia Governorate Egypt, to determine the critical period of weed/ soybean competition as affected by plant density. These treatments were arranged in split-plot design, with four replications was used in this experiment. Each experiment included 30 treatments which were the combination of three plant densities and ten weed removal or competition periods. Plant density was arranged in the main plots according to the procedure followed by (Dawson 1970) which were:

1-105000 plants/fad.

2- 140000 plants/fad.

3- 175000 plants/fad. as follows:

Weed free and weed competition treatments were assigned in sub-plots

1- Weed free for whole season (W.F).

2- Weed free for 3 weeks after transplanting.

3- Weed free for 6 weeks after transplanting.

4- Weed free for 9 weeks after transplanting.

5 - Weed free for 12 weeks after transplanting.

6- Weed infestation for whole season (W.I).

7- Weed infestation for 3 weeks after transplanting.

8- Weed infestation for 6 weeks after transplanting.

9- Weed infestation for 9 weeks after transplanting.

10- Weed infestation for 12 weeks after transplanting.

After soil preparation, the main plot area divided into four sub plots each plot was $10.5 \mathrm{~m}^{2}$ which consisted of five rows, $3.5 \mathrm{~m}$ length and $0.6 \mathrm{~m}$ width. Herati method was used in this study. Seeds of Giza 111 cultivars were planted in 31 May and 17 June in both seasons, respectively. Experimental soil was clay and chemical analysis of the tested soil were determined according to Jackson (1958), presented in Table (1).

Table (1): Physical and chemical analysis of the experimental soil from the depth of $(0-30 \mathrm{~cm}$.$) .$

\begin{tabular}{|l|c|l|c|}
\hline \multicolumn{2}{|c|}{ Chemical analysis } & \multicolumn{2}{c|}{ Mechanical analysis } \\
\hline Organic mater \% & 1.81 & Coarse sand & 4.75 \\
\hline Total N \% & 0.19 & Fine sand & 20.00 \\
\hline Available N (ppm) & 35.15 & Silt & 23.81 \\
\hline Available P (ppm) & 6.90 & Clay & 51.43 \\
\hline Available K(ppm) & 200.00 & & \\
\hline Total soluble. Salts(m eq./100g soil) & 0.27 & & \\
\hline $\mathrm{PH}$ & 7.9 & & \\
\hline
\end{tabular}


The recommended cultural practices were carried out throughout the two growing seasons expect weed control treatments.

\section{Data recorded}

\section{A- Weed measurement}

One sample weed was hand pulling from one $\mathrm{m}^{2}$ of each sub plot was taken at harvest, separated to grassy and broad-leaf and oven dried at $70^{\circ} \mathrm{C}$ until a constant weight to record the total annual weeds and recorded as $\mathrm{g} / \mathrm{m}^{2}$

\section{B-Seed yield and its components:}

At harvest, the following parameters were determined in a sample of five random guarded plants from each sub plot:-

1- Plant height $(\mathrm{cm})$.

2- Number of branches/plant.

3- Number of seeds/pod.

4- Weight of seeds/plant (g).

5- Weight of 100 seed $(\mathrm{g})$.

6- Seed yield (ton/fad.) was calculated from the whole sub plot area.

C- Chemical analyses.

1- Oil content \%

Oil content of soybean seeds was determined by soxhlet apparatus on a dry weight basis as described by Sorenson (1947).

\section{2- Protein content \%}

Protein was determined as total nitrogen by micro-Kjeldahl method, according to A.O.A.C. (1975), then, $\mathrm{N}$ was multiplied by 6.25 (Tripathi et al.,1971) to obtain protein content in soybean seeds.

\section{D- Estimation critical weed control period:}

Data of each season were statistically analyzed according to the procedures outlined by Gomez and Gomez (1984) and the treatments means were compared by least significant differences (L.S.D.). The relative and actual yield were subjected to analysis of variance using Regression Curve Estimation Functions to analysis of Statistical producers for social sciences (SPSS 12.0 for windows), to evaluate the effect of the length of the weed free period and increasing duration of weed interference on relative lentil yields (Evans et al., 2003; Knezevic et al., 2002 and Norsworthy and Oliveira, 2004). Relative yield of each treatment was calculated in percent of the corresponding weed-free yield. Three response curve models namely, linear, quadratic and logistic were fitted to study the relationships between yield/fed and duration of weed-free or weed-competition period during first and second seasons. First and second model are linear and quadratic according to Neter et al., (1990). A three model logistic equation proposed by Hall et al., (1992) and modified by Knezevic et al., (2003), was used to describe the relation between increasing duration weed interference on relative yield to determine the onset of critical period of weed control. Also, logistic regression model is presented in Agresti (1996). The dependent or response and independent or predictor variables in this model area categorical, continuous or a mix of continuous and categorical (Tabachick and Fidell 1996) use the term polychotomous]. The independent or predictor variables in logistic regression 
can take any form. That is, logistic regression makes no assumption about the distribution of the independent variables. They do not have to be normaly distributed, linearly related or of equal variance within each group.

Statistical techniques:

* Linear model is estimated using the formula:

$$
Y=a+b x
$$

Where: $Y=$ is the seed yield/fed in ardab.

$$
a: \text { is the } Y \text { intercept. }
$$

$b:$ is the linear coefficient of regression.

Competition period.

$\mathrm{x}:$ is the duration of applied weed-free or weed.

* Quadratic polynomial model is computed using the formula:

Where: $Y=$ is the seed yield/fed in ardab.

$$
\mathrm{Y}=\mathrm{a}+\mathrm{bx}+\mathrm{cx}^{2}
$$

$a:$ is the $Y$ intercept.

$\mathrm{b}:$ is the linear coefficient of regression.

$c:$ is the quadratic coefficient of regression.

$X:$ is the duration of applied weed-free or weed-competition period.

* Logistic regression equation is computed using the formula:

$$
\begin{gathered}
Y=1 /\left(1 / u+\left(b 0^{*}\left(b 1^{*}{ }^{*} t\right)\right)\right) \\
\text { Or }=\ln (1 / y-1 / u) \quad \text { Or } Y=\ln (b o)+\left(\ln (b 1)^{*} t\right)
\end{gathered}
$$

Where: $U=$ is the upper boundrn value of $y$. The value must be a positive no/greater than the largest dependent variable value.

$\mathrm{b} 0=$ is the constant $(\mathrm{a})$.

$\mathrm{b} 1=$ is the regression coefficient.

$T=$ is the independent variable, $x$.

Data were analysis statistical by Central Laboratory for design and statistical analysis Research, Agriculture Research Center, Giza, Egypt.

\section{RESLTUS AND DISCUSSION}

It should be noted that the experimental field was naturally heavily infested by mixed annual weed spices. The dominant annual broad-leaf weeds were Xanthium brasilicum, Portulaca oleracea L., Amaranthus ascendens and Corchorus olitorius $\mathrm{L}$. and the dominant annual grasses were Echinochloa colonum, Dinebra retroflexa, Digitaria sanguinalis L. and Setaria viridis.

From the weed infestation for all season treatments in table (3), the respective infestation rates under 105,140 and 175 thousands soybean plants $/ \mathrm{m}^{2}$ were 2.43 and 2.38 ton dry weight/fed in 2009 and 2010 seasons.

1- Effect of plant density on total annual weeds, yield and yield component and chemical characters.

These results sure enough that increasing plant density from 105 to 175 thousand plant/fad. gradually decreasing weeds dry weight.

The data obtained for yield and yield components of soybean which are given in Table (2), the plant densities had significant effect on it. 
In the respective both seasons, the highest values of plant length was obtained by 175000 plant/fed $(102.5$ and $105.1 \mathrm{~cm})$; followed by 140000 plants $(96.0$ and $99.0 \mathrm{~cm}$ ). Meanwhile 140000 plants/fed gave the highest values of No. of seed/pod by 2.58 and 2.7, weight of 100 seed by 18.85 and $22.0 \mathrm{~g}$ and seed yield by 1.43 and 1.49 ton/fad. 105000 plants gave the highest values of No. of branches, by 2.61 and 2.70 and seed weight/plant 18.08 and 21.2 of the previous characteristics.

That mean the best plant density on growth and yield of soybean was 140000 plants/fed followed by 105000 plants. Also results showed that the effect of plant density was not significant on oil percentage and protein percentage in the first and second seasons.

Table (2): Effect of plant density treatments on dry weight of mixture annual weed, yield and yield component in 2009 and 2010 seasons.

\begin{tabular}{|c|c|c|c|c|c|c|c|c|c|}
\hline $\begin{array}{l}\text { Plant } \\
\text { density }\end{array}$ & $\begin{array}{l}\text { Weed } \\
\left(\mathrm{g} / \mathrm{m}^{2}\right)\end{array}$ & $\begin{array}{c}\text { Plant } \\
\text { length } \\
\text { (cm) }\end{array}$ & $\begin{array}{c}\text { No. of } \\
\text { branches/ } \\
\text { plant }\end{array}$ & $\begin{array}{c}\text { Seed } \\
\text { weight/ } \\
\text { plant(g) }\end{array}$ & $\begin{array}{c}\text { No. of } \\
\text { seed/pod. }\end{array}$ & \begin{tabular}{|c|}
$\begin{array}{c}\text { Weight } \\
\text { of } 100 \\
\text { seed } \\
(\mathrm{g})\end{array}$ \\
\end{tabular} & $\begin{array}{c}\text { Yield } \\
\text { ton/fad. }\end{array}$ & Oil \% & $\begin{array}{c}\text { Protein } \\
\%\end{array}$ \\
\hline \multicolumn{10}{|c|}{2009 season } \\
\hline \multirow{4}{*}{$\begin{array}{l}105 \\
140 \\
175\end{array}$} & $155.7 a$ & $91.15 c$ & $2.61 \mathrm{a}$ & $18.08 \mathrm{a}$ & $2.45 b$ & $17.85 b$ & $1.28 b$ & $22.50 a$ & $38.72 a$ \\
\hline & $147.5 b$ & $95.98 b$ & $2.48 \mathrm{~b}$ & $17.43 b$ & $2.58 \mathrm{a}$ & $18.85 a$ & $1.43 a$ & $22.80 \mathrm{a}$ & $38.83 a$ \\
\hline & $142.1 \mathrm{c}$ & $102.50 \mathrm{a}$ & $2.25 c$ & $15.17 \mathrm{c}$ & $2.40 \mathrm{c}$ & $16.35 c$ & $1.17 \mathrm{c}$ & $22.40 \mathrm{a}$ & $38.76 a$ \\
\hline & \multicolumn{9}{|c|}{2010 season } \\
\hline 105 & $144.2 \mathrm{a}$ & $92.60 c$ & $2.70 a$ & $21.20 \mathrm{a}$ & $2.60 \mathrm{~b}$ & $20.30 \mathrm{~b}$ & $1.30 \mathrm{~b}$ & $22.70 a$ & $38.83 a$ \\
\hline 140 & $141.0 \mathrm{~b}$ & $99.00 \mathrm{~b}$ & $2.50 \mathrm{~b}$ & $19.00 \mathrm{~b}$ & $2.70 \mathrm{a}$ & $22.00 \mathrm{a}$ & $1.49 c$ & $22.50 \mathrm{a}$ & $38.80 a$ \\
\hline 175 & $138.3 c$ & $105.10 \mathrm{a}$ & $2.30 \mathrm{c}$ & $17.10 \mathrm{c}$ & $2.50 \mathrm{c}$ & $18.70 \mathrm{c}$ & $1.26 \mathrm{a}$ & $22.60 \mathrm{a}$ & $38.79 a$ \\
\hline
\end{tabular}

2- Effect of weed free and weed competition periods on total annual weeds, yield and yield component and chemical characters.

From the weed infestation for all season treatments in table (3), the respective infestation rates under 105, 140 and 175 thousands soybean plants $/ \mathrm{m}^{2}$ were 2.43 and 2.38 ton dry weight/fed in the first and second seasons.

Data in Table (3) show that weed free for the whole season decreased the dry weight of total weeds by 94.2 and $94.2 \%$ as compared to weed competition for the whole season in 2009 and 2010 seasons. Weed competition for the whole season gave the highest decrease in seed yield by 37.6 and $34.4 \%$ ) under 579.3 and $565.5 \mathrm{~g} / \mathrm{m}^{2}$ dry weight of total annual weeds in 2009 and 2010 seasons.

Such decrease in seed yield was significantly correlated with yield component namely No. of branches/plant, plant length, seed weight/plant, No. of seed/pod and weight of 100 seed

Results in table (3) showed that the effect of weed infestation treatment was not significant on oil percentage and protein percentage in the first and second seasons. 
J. Plant Production, Mansoura Univ., Vol. 3 (9), September, 2012

T3 
3- Effect of interaction between weed infestation periods and plant density on mixed annual weeds, yield and yield component and chemical characters.

The interaction between weed -free for the whole season under 175000 plant/fad. gave the highest reduction of dry weight of mixed annual weeds $\left(30.93\right.$ and $\left.31.27 \mathrm{~g} / \mathrm{m}^{2}\right)$. While the lowest reduction was obtain by weed infestation all under 105000 plant/fad. (606.6 and $\left.570.5 \mathrm{~g} / \mathrm{m}^{2}\right)$, respectively in the first and second seasons (Table 4).

Table (4): Effect of interaction between plant density and weed infestation treatment on dry weight of mixture annual weeds in 2009 and 2010 seasons.

\begin{tabular}{|c|c|c|c|c|c|c|}
\hline Season & \multicolumn{3}{|c|}{2009 season } & \multicolumn{3}{|c|}{2010 season } \\
\hline $\begin{array}{l}\text { Weed removal or } \\
\text { competition periods }\end{array}$ & $\begin{array}{c}\text { Plant } \\
\text { density } \\
105 \\
\text { thousand } \\
\text { /fad }\end{array}$ & \begin{tabular}{|c|} 
Plant \\
density \\
140 \\
Thousand \\
/fad
\end{tabular} & \begin{tabular}{|c|} 
Plant \\
density \\
175 \\
Thousand \\
/fad
\end{tabular} & \begin{tabular}{|c|} 
Plant \\
density \\
105 \\
$\begin{array}{c}\text { Thousand } \\
\text { /fad }\end{array}$ \\
\end{tabular} & \begin{tabular}{|c|} 
Plant \\
density \\
140 \\
Thousand \\
/fad \\
\end{tabular} & \begin{tabular}{|c|} 
Plant \\
density \\
175 \\
thousand \\
/fad \\
\end{tabular} \\
\hline Weed free all season & 36.73nop & 33.54op & $30.93 p$ & 34.06uv & $32.49 v$ & $31.27 v$ \\
\hline Weed free 12 weeks & $42.96 \mathrm{klmno}$ & 40.88Imnop & 39.08mnop & 39.69rs & $37.76 \mathrm{st}$ & $35.95 \mathrm{tu}$ \\
\hline Weed free 9 weeks & $82.02 \mathrm{i}$ & \begin{tabular}{|l|}
$79.46 \mathrm{i}$ \\
\end{tabular} & $75.96 \mathrm{i}$ & $75.23 \mathrm{j}$ & 73.47jk & $71.83 \mathrm{k}$ \\
\hline Weed free 6 weeks & $244.5 \mathrm{~g}$ & $234.6 \mathrm{~h}$ & $228.6 h$ & $220.6 \mathrm{~g}$ & $212.2 \mathrm{~h}$ & $208.3 i$ \\
\hline Weed free 3 weeks & $335.6 \mathrm{~d}$ & $317.3 \mathrm{e}$ & $307.3 f$ & $313.8 d$ & $306.5 \mathrm{e}$ & $301.6 f$ \\
\hline Weed infestation all season & $606.6 a$ & $575.7 b$ & $555.5 c$ & $570.5 a$ & $566.6 b$ & $559.4 \mathrm{c}$ \\
\hline Weed infestation 12 weeks & $56.35 j$ & $52.07 \mathrm{jk}$ & $49.61 \mathrm{jk} / \mathrm{m}$ & 51.931 & $49.45 \mathrm{Im}$ & $47.31 \mathrm{~m}-\mathrm{O}$ \\
\hline Weed infestation 9 weeks & 53.36jk & 49.69jklm & 46.89jklmn & $48.28 \mathrm{mn}$ & $46.47 \mathrm{no}$ & 45.01op \\
\hline Weed infestation 6 weeks & $50.36 \mathrm{jkl}$ & 46.52jklmn & $44.31 \mathrm{klmn}$ & 46.1 no & 44.49op & $42.72 \mathrm{pq}$ \\
\hline Weed infestation 3 weeks & $48.51 \mathrm{jk} / \mathrm{m}$ & 45.67jklm & 42.83kImno & $42.25 p-r$ & $40.92 q r$ & 39.65 rs \\
\hline
\end{tabular}

The interaction between weed free for the whole season under 175000 plants/fad. gave the tallest plants $(119.8$ and $120.5 \mathrm{~cm})$ but the shortest plants $(79.9$ and $80.0 \mathrm{~cm}$ ) was obtained from weed infestation all season under 105000 plants/fed in first and second seasons, respectively. The best values of No. of branches/plant and seed weight/plant were (3.3 and 3.4), (46.95 and 53.9), (42.95 and 42.0) and (25.7 and 31.2) respective due to applied weed free for all season under 105000 plant/fad. While the lowest values of these characteristics were obtained by infestation for all season under 175000 plants/fad. (1.6 and 1.7), (17.1 and 18.2), (14.85 and 15.4) and (9.3 and 10.5).

The application weed free for the whole season under 140000 plant/fed gave the highest values of No. of seed/pods weight of 100 seed and yield ton/fed by 2.9 and 3.0), (25.5 and 29.0) and (1.77 and 1.80) while the lowest values were obtained from weed infestation for all season and 175000 plant/fad. (20 and 2.0), 8.5 and 10.0) and (0.82 and 0.92) in the first and second seasons, respectively (Tables 5 ). 
Table (5): Effect of interaction between plant density and weed infestation treatment on yield and yield component in 2009 season.

\begin{tabular}{|c|c|c|c|c|c|c|c|c|c|}
\hline \multirow{2}{*}{$\begin{array}{c}\text { Characters } \\
\text { Weed removal or } \\
\text { competition periods }\end{array}$} & \multicolumn{3}{|c|}{ Plant length (cm) } & \multicolumn{3}{|c|}{ No. of branches/plant } & \multicolumn{3}{|c|}{ Seed weight/plant } \\
\hline & 105 & 140 & 175 & 105 & 140 & 175 & 105 & 140 & 175 \\
\hline \multicolumn{10}{|c|}{2009 season } \\
\hline Weed free all season & $106.7 \mathrm{~cd}$ & $110.8 \mathrm{~b}$ & $119.8 a$ & $3.3 a$ & $3.05 b c$ & $2.6 g-i$ & $25.7 a$ & $24.7 b$ & $21.8 \mathrm{e}$ \\
\hline Weed free 12 weeks & 100.9ef & $106.1 \mathrm{~cd}$ & $111.6 \mathrm{~b}$ & $2.8 \mathrm{ef}$ & $2.7 f g$ & $2.55 \mathrm{~h}-\mathrm{j}$ & $23.3 c$ & $22.6 \mathrm{~d}$ & $19.7 f g$ \\
\hline Weed free 9 weeks & $84.3 \mathrm{mn}$ & 95.4gh & 103.7de & $2.7 f g$ & $2.65 \mathrm{gh}$ & 2.45jk & $19.5 \mathrm{~g}$ & $18.9 \mathrm{~h}$ & $16.3 i$ \\
\hline Weed free 6 weeks & $81.7 \mathrm{no}$ & $90.5 \mathrm{jk}$ & $98.3 f g$ & $2.4 \mathrm{k}$ & 2.25 & $2.05 \mathrm{~m}$ & $16.5 i$ & 15.3k & $13.6 \mathrm{~m}$ \\
\hline Weed free 3 weeks & $81.1 \mathrm{no}$ & $84.0 \mathrm{mn}$ & $91.5 \mathrm{ij}$ & $2.0 \mathrm{mn}$ & $1.9 \mathrm{no}$ & $1.75 p$ & 14.41 & $12.8 n$ & 11.70 \\
\hline Weed infestation all season & 79.90 & 81.6 no & $87.6 \mathrm{kl}$ & $2.0 \mathrm{mn}$ & $1.75 p$ & $1.6 q$ & $11.0 p$ & $10.7 p$ & $9.3 r$ \\
\hline Weed infestation 12 weeks & $86.6 \mathrm{Im}$ & & & 2.21 & $2.05 \mathrm{~m}$ & $1.8 \mathrm{op}$ & $13.1 n$ & $12.9 n$ & $10.2 q$ \\
\hline Weed infestation & 90jk & 94.4hi & $102.3 \mathrm{e}$ & $2.7 g h$ & $2.5 \mathrm{i}-\mathrm{k}$ & 2.25 & $15.8 \mathrm{j}$ & 15.5jk & $13.7 \mathrm{~m}$ \\
\hline Weed infest & $98.1 \mathrm{fg}$ & 101. & $107.4 \mathrm{C}$ & $3.0 \mathrm{~cd}$ & 2.9de & $2.65 \mathrm{gh}$ & $20.0 f$ & $19.6 f g$ & $16.5 i$ \\
\hline Weed infesta & $102.2 \mathrm{e}$ & $106.8 \mathrm{~cd}$ & $110.8 \mathrm{~b}$ & $3.1 \mathrm{~b}$ & $3.0 b-d$ & 2.8ef & $21.7 \mathrm{e}$ & $21.5 \mathrm{e}$ & $19.1 \mathrm{~h}$ \\
\hline Characters & \multicolumn{3}{|c|}{ No. of seed/pod. } & \multicolumn{3}{|c|}{ Weight of 100 seed } & \multicolumn{3}{|c|}{ Yield ton/fad. } \\
\hline Weed free all se & $2.75 \mathrm{~cd}$ & $2.9 \mathrm{a}$ & $2.8 \mathrm{bc}$ & $24.5 \mathrm{a}$ & $25.5 a$ & $21.5 b c$ & $1.51 \mathrm{e}$ & $1.77 a$ & $1.42 \mathrm{~g}$ \\
\hline Weed free & $2.65 \mathrm{ef}$ & $2.8 \mathrm{bc}$ & $2.65 \mathrm{ef}$ & $20.5 \mathrm{~cd}$ & $21.5 b c$ & 19.5de & $1.47 f$ & $1.70 \mathrm{~b}$ & $1.36 \mathrm{i}$ \\
\hline Weed free $s$ & $2.5 \mathrm{hi}$ & & & 19.5de & & $17.5 \mathrm{fgh}$ & $1.41 \mathrm{~h}$ & & $1.32 \mathrm{j}$ \\
\hline Weed free 6 & $2.42 \mathrm{j}$ & $2.55 \mathrm{gh}$ & $2.4 \mathrm{j}$ & $17.5 \mathrm{fgh}$ & 19.5de & \begin{tabular}{|l|} 
16.0hi \\
\end{tabular} & $1.42 \mathrm{~h}$ & $1.60 \mathrm{~d}$ & $1.25 \mathrm{k}$ \\
\hline Weed free 3 & 2.2 & & $2.1 \mathrm{~m}$ & 16.5ghi & 16.5ghi & $15.0 \mathrm{ij}$ & $1.05 p$ & $1.28 \mathrm{j}$ & $1.03 q$ \\
\hline Weed infestation & $2.1 \mathrm{~m}$ & 2.21 & $2.0 n$ & $10.5 \mathrm{~m}$ & $11.0 \mathrm{~lm}$ & $8.5 n$ & $1.00 \mathrm{r}$ & $1.05 p$ & $0.90 t$ \\
\hline Weed infest & 2.21 & $2.3 \mathrm{k}$ & $2.1 \mathrm{~m}$ & $12.5 \mathrm{kl}$ & $13.5 \mathrm{jk}$ & $15.0 \mathrm{ij}$ & $1.03 q$ & & $95 \mathrm{~s}$ \\
\hline Weed infest & $2.4 \mathrm{j}$ & $2.5 \mathrm{hi}$ & $2.3 \mathrm{k}$ & $16.5 \mathrm{ghi}$ & $17.5 \mathrm{fgh}$ & 14.0jk & $1.09 \mathrm{no}$ & $1.15 \mathrm{~m}$ & $1.00 r$ \\
\hline Weed infest & $2.6 f g$ & 2.75 & $2.45 i j$ & 18.0efg & 19.0d-f & 16.0hi & 1.201 & $5 \mathrm{k}$ & 1.080 \\
\hline Weed infestation 3 weeks & $2.70 \mathrm{de}$ & $2.85 a b$ & $2.60 \mathrm{fg}$ & $22.5 b$ & $24.5 \mathrm{a}$ & $20.5 \mathrm{~cd}$ & $1.51 \mathrm{e}$ & & $1.46 f$ \\
\hline \multicolumn{10}{|c|}{2010 season } \\
\hline & \multicolumn{3}{|c|}{ Plant length (cm) } & \multicolumn{3}{|c|}{ No. of branches/plant } & \multicolumn{3}{|c|}{ Seed weight/plant } \\
\hline $\begin{array}{l}\text { Weed removal } \\
\text { competition periods }\end{array}$ & 105 & 140 & 175 & 105 & 140 & 175 & 105 & 140 & 175 \\
\hline Weed free all s & 109.9ef & $112.7 \mathrm{bc}$ & $120.5 a$ & $3.4 \mathrm{a}$ & $3.2 \mathrm{~b}$ & $2.7 e-h$ & $31.2 a$ & $27.0 \mathrm{~b}$ & $24.8 d$ \\
\hline Weed free 12 & 104.0h & $108.5 \mathrm{e}-\mathrm{g}$ & $112.0 \mathrm{~cd}$ & $3.0 \mathrm{~d}$ & $2.8 d-g$ & $2.4 \mathrm{j}-\mathrm{I}$ & $27.2 b$ & $24.8 d$ & $21.3 g$ \\
\hline Weed free & $85.4 n$ & $97.6 \mathrm{j}$ & $107.4 \mathrm{~g}$ & 2.9de & $2.6 \mathrm{~g}-\mathrm{j}$ & $2.3 \mathrm{k}-\mathrm{m}$ & $23.9 \mathrm{e}$ & $20.9 g$ & $18.9 i$ \\
\hline ed free & 2.50 & & & $2.4 \mathrm{j}-1$ & $2.21-n$ & $2.1 \mathrm{no}$ & 19.8h & 17.jk & 15.91 \\
\hline Wee & $1.4 \mathrm{op}$ & & & 2.2I-n & & 1.9op & $16.2 \mid$ & $13.8 n$ & 12.70 \\
\hline Weec & 80.0p & 82. & & 2.00 & $1.8 p q$ & $1.7 q$ & 12.60 & $11.4 p$ & $10.5 q$ \\
\hline Weec & 90.2lm & & & $2.3 \mathrm{k}-\mathrm{m}$ & $2.1 \mathrm{~m}-\mathrm{o}$ & $1.8 \mathrm{pq}$ & $14.9 m$ & $13.2 \mathrm{no}$ & 12.70 \\
\hline Weed & 92.01 & 102.1hi & $107.3 \mathrm{~g}$ & $2.6 f-i$ & $2.5 \mathrm{i}-\mathrm{k}$ & $2.3 \mathrm{k}-\mathrm{m}$ & 17.0k & $14.7 \mathrm{~m}$ & $13.4 n$ \\
\hline Weec & $97.4 \mathrm{j}$ & & & $3.0 d$ & 2.9de & $2.6 f-i$ & $22.5 f$ & $9 g$ & $17.8 \mathrm{j}$ \\
\hline Weed infestation 3 weeks & 102.8hi & $108.1 \mathrm{fg}$ & $114.3 b$ & $3.2 b$ & $3.0 d$ & $2.8 \mathrm{~d}-\mathrm{g}$ & $26.3 c$ & $25.0 d$ & $22.9 f$ \\
\hline Characters & \multicolumn{3}{|c|}{ No. of seed/pod. } & \multicolumn{3}{|c|}{ Weight of 100 seed } & \multicolumn{3}{|c|}{ Yield ton/fad. } \\
\hline Weed free all s & $2.9 \mathrm{bcd}$ & $3.0 \mathrm{ab}$ & 2.8ef & $27.0 \mathrm{~b}$ & 29.0a & $25.3 c-e$ & $1.57 d$ & $1.75 a$ & $1.48 f$ \\
\hline Weed free 1 & $2.8 \mathrm{ef}$ & 2.8de & $2.6 \mathrm{gh}$ & $25.0 d-f$ & $26.3 b c$ & $24.0 f g$ & $1.54 \mathrm{e}$ & $1.68 b$ & $1.45 \mathrm{~g}$ \\
\hline Weed free 9 & 2.6hi & $2.7 f$ & $2.5 \mathrm{ij}$ & $21.7 \mathrm{ij}$ & 23.0gh & $19.7 \mathrm{k}$ & $1.49 f$ & $1.60 \mathrm{c}$ & $1.41 \mathrm{~h}$ \\
\hline Weed free 6 & $2.5 i j$ & $2.6 \mathrm{gh}$ & $2.4 \mathrm{jk}$ & 19.3kl & $21.7 \mathrm{ij}$ & 17.3no & $1.45 \mathrm{~g}$ & $1.57 d$ & $1.38 i$ \\
\hline Weed free 3 weeks & $2.4 \mathrm{k}$ & & $2.3 \mid$ & 18.3I-n & $19.7 \mathrm{k}$ & 17.00 & $1.25 \mathrm{~m}$ & $1.35 \mathrm{j}$ & $1.23 n$ \\
\hline Weed infestation all sea & $2.1 \mathrm{~m}$ & & $2.0 \mathrm{~m}$ & $13.0 \mathrm{q}$ & $14.7 p$ & 10.0r & $1.00 t$ & 1.200 & $0.95 u$ \\
\hline Weed infest & $2.4 \mathrm{k}$ & $2.5 i j$ & 2.21 & $15.3 p$ & 17.00 & $14.7 p$ & $1.02 \mathrm{~s}$ & $1.28 \mathrm{I}$ & $0.99 t$ \\
\hline Weed infestation 9 weeks & $2.7 f$ & $2.9 \mathrm{~cd}$ & $2.5 i j$ & $18.0 \mathrm{~m}-\mathrm{0}$ & $20.0 \mathrm{k}$ & 17.00 & $1.12 q$ & $1.32 \mathrm{k}$ & $1.12 q$ \\
\hline & $2.9 \mathrm{~cd}$ & & $2.7 f g$ & $21.3 \mathrm{j}$ & 23.0gh & 19.0k-m & $1.10 r$ & $1.41 \mathrm{~h}$ & $1.15 p$ \\
\hline ation 3 weeks & $2.9 a b c$ & $3.0 a b$ & $2.8 \mathrm{de}$ & 24.3ef & $25.7 \mathrm{~cd}$ & 22.7hi & $1.49 f$ & $1.75 a$ & $1.46 \mathrm{~g}$ \\
\hline
\end{tabular}




\section{Determination critical period of weed control as affected by weed and plant density.}

Obtaining 100 percentage seed yield for soybean crop for free season from weeds ( 15 weeks) is high costing. So, obtaining $90 \%$ seed yield is accepted by determining critical period of weed control (CPWC) according to the recommended allowed losing yield value (10\%). To achieve this target, the relation among seed yield and each of weed -free and weed competition was studied using some type of curves namely: Linear, logistic and quadratic models. Three bases were considered to compare among the three models i.e. coefficient of determination $\left(R^{2}\right)$, standard error of estimate (SE) and the significance of the model. The significant model which had highest $R^{2}$ and lowest SE was the best model fitted to the yield data.

Table (6) clear the value of coefficient of determination $\left(R^{2}\right)$, standard error of estimate (SE) and calculated $F$ value of the tested models in 2009 and 2010 seasons. Results clearly present that the highest value of coefficient of determination $\left(R^{2}\right)$, was in favour of logistic model for weed-free and weed competition in 2009 season and quadratic model for weed-free and weed competition in 2010 season.

The results of coefficient of determination $\left(R^{2}\right)$ being 0.96 and 0.97 for weed free and being 0.97 and 0.94 for the weed competition over all treatments of the two seasons, respectively.

Data clearly present that the critical period of weed control over all studied agricultural practices according to the recommended allowed losing yield value (10\%) being 6.45 and 6.4 weeks for weed-free and being 4.9 and 4.65 weeks for weed-competition in the first and second seasons, respectively. These results showed that, the critical of weed control didn't differ more than individual agricultural practices that were studied. These accepted models had lost values of standard error of estimated compared with models and they had significant calculated if value in the two seasons. So, these models were the best of the response models tested for describing the relation between seed yield of soybean to weed-free and weed competition, (Figs. 1).

This finding was in conformity with that obtained by (Delayed et al., 2007) found that, plots left unweeded inevitably had the highest yield reduction. On the other hand, plots weeded at 2 and 6 week after sowing showed the best performance in all aspects. 
Table (6): Parameters of three models that were studied on the effect of weed control treatments on soybean seed yield in 2009 and 2010 seasons.

\begin{tabular}{|c|c|c|c|c|c|c|c|}
\hline Season & Treatments & Methods & R2 & S. E. & Sig. & Prediction equation & $\begin{array}{l}\text { CPWC/ week } \\
\text { allowed losing } \\
\text { yield (10\%) }\end{array}$ \\
\hline $\begin{array}{l}2009 \\
\text { season }\end{array}$ & $\begin{array}{l}\text { Weed-free } \\
\text { Weed } \\
\text { competition }\end{array}$ & \begin{tabular}{|l|} 
Linear \\
Logistic \\
Quadratic \\
Linear \\
Logistic \\
Quadratic
\end{tabular} & \begin{tabular}{|l|}
0.852 \\
0.964 \\
0.957 \\
0.806 \\
0.631 \\
0.967
\end{tabular} & \begin{tabular}{|l|}
0.077 \\
0.038 \\
0.05 \\
0.11 \\
0.152 \\
0.056
\end{tabular} & \begin{tabular}{|l|}
0.025 \\
0.003 \\
0.043 \\
0.385 \\
0.109 \\
0.033
\end{tabular} & $\begin{array}{l}Y=1.103+0.335 x \\
Y=\ln (0.857)+\ln (0.267) x \\
Y=0.894+0.934 \times 1-0.003 \times 2 \\
Y=0.789+0.041 x \\
Y=\ln (0.6)+\ln (0.271) x \\
Y=1.114-0.052 \times 1+0.005 \times 2\end{array}$ & 6.45 \\
\hline $\begin{array}{l}2010 \\
\text { season }\end{array}$ & $\begin{array}{l}\text { Weed-free } \\
\text { Weed } \\
\text { competition }\end{array}$ & \begin{tabular}{|l|} 
Linear \\
Logistic \\
Quadratic \\
Linear \\
Logistic \\
Quadratic
\end{tabular} & \begin{tabular}{|c|}
0.873 \\
0.97 \\
0.956 \\
0.798 \\
0.632 \\
0.945
\end{tabular} & \begin{tabular}{|l|}
0.052 \\
0.025 \\
0.037 \\
0.106 \\
0.143 \\
0.068
\end{tabular} & $\begin{array}{l}0.02 \\
0.002 \\
0.044 \\
0.041 \\
0.108 \\
0.055\end{array}$ & $\begin{array}{l}Y=1.258+0.025 x \\
Y=\ln (1.08)+\ln (0.194) x \\
Y=1.123+0.063 \times 1-0.002 \times 2 \\
Y=0.873+0.39 x \\
Y=\ln (0.693)+\ln (0.256) x \\
Y=1.166-0.045 \times 1+0.005 \times 2\end{array}$ & 4.65 \\
\hline
\end{tabular}
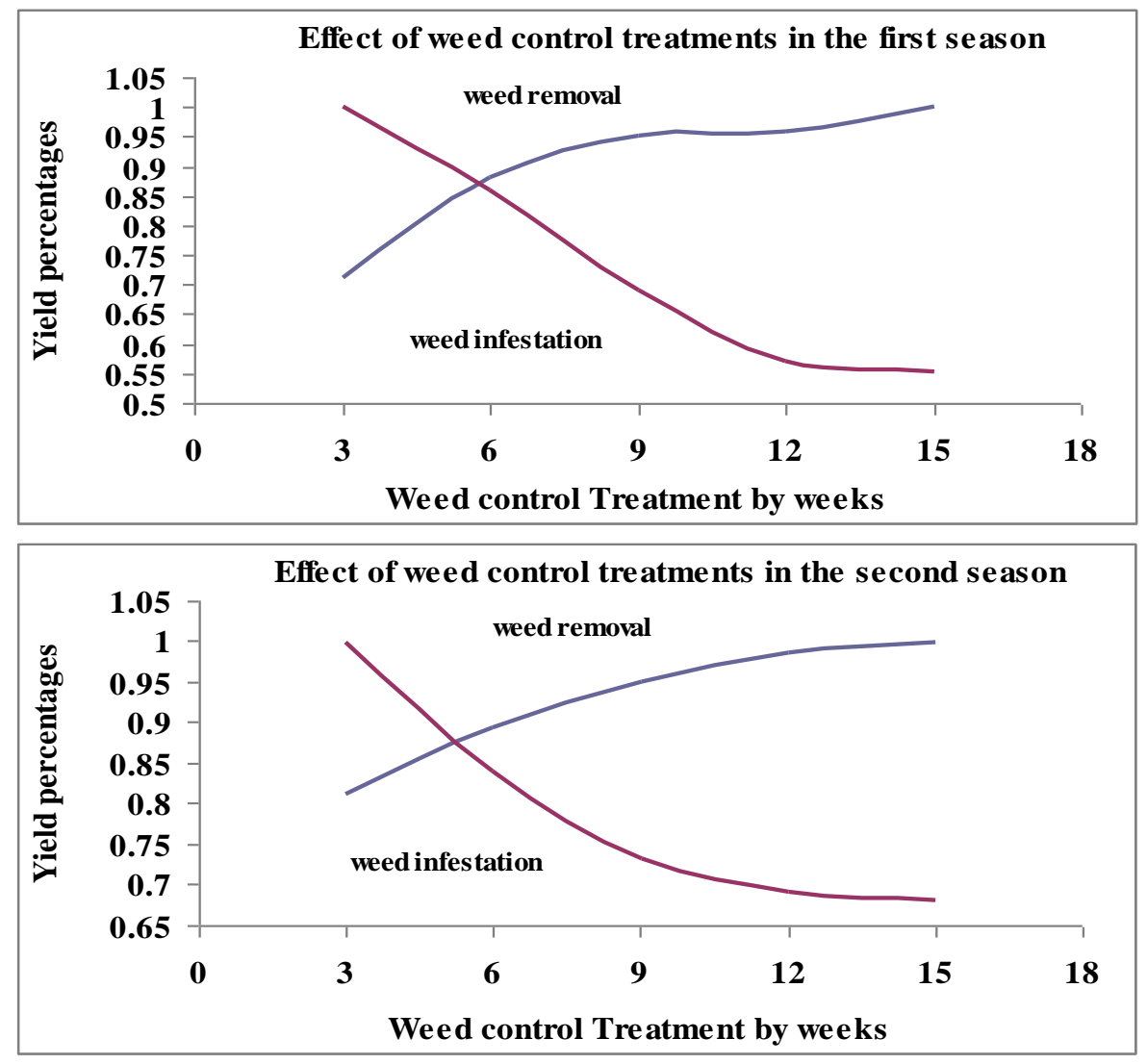

Fig (1). Effect of weed control treatments in the first season and second. 


\section{Critical period as affected by soybean plant density.}

Data in table (7) clear coefficient of determination $\left(R^{2}\right)$, standard error of estimate (SE) and calculated $F$ values of three tested models to study response of soybean seed yield to weed-free and weed-competition during 2009 and 2010 seasons.

Results of 105 thousand plant/fad., density all the study clearly shows that the highest value of coefficient of determination $\left(R^{2}\right)$ was in favor quadratic model for weed-free and weed-competition in two seasons, respectively. The values of $\left(R^{2}\right)$ were 0.91 and 0.98 for weed-free and 0.96 and 0.98 for weed-competition in two seasons, respectively.

Results of 140 thousand plant/fad., density the values $\left(R^{2}\right)$ were 0.94 for logistic model of the weed-free in first season and 0.95 for quadratic model of the weed-free in the second season, meanwhile 0.97 for logistic model for weed-competition in the first season and 0.95 for quadratic model for weed-competition in the second season.

Using 175 thousand plant/fed density. the highest value of $\left(R^{2}\right)$, for weed-free was of quadratic and for the weed-competition it was in favor logistic in the first seasons, respectively. These values were 0.99 and 0.97 for weed-free and weed-competition. In the second season the highest values of $\left(R^{2}\right)$, for weed-free and weed competition were of quadratic by 0.97 and 0.96 for weed-free and weed competition.

According to the recommended allowed losing yield value (10\%), table (7) and Figs. (2 \& 3) clear that critical period of weed control under 105 thousand plant/fad. was 6.5 and 4.25 weeks for weed-free and weedcompetition, respectively. In the second season the corresponding value of critical period of weed control was 7.0 and 4.25 weeks for weed-free and weed-competition. Under 140 thousand plant/fad., to accept of $90 \%$ seed yield using accepted fitted model equations for the critical period of weed control, the values equal 6.2 and 3.9 weeks for weed-free and weedcompetition in the first season, respectively. In the second season the critical period was 6.3 and 4.2 weeks for weed-free and weed-competition. Using 175 thousand plant/fad., By accepted fitted model equation according to the allowed losing yield value $10 \%$ and accepting $90 \%$ seed yield in the same table and figs. the critical period being (5.9 and 3.5 weeks) and (5.6 and 4.15 weeks) for weed free and weed competition in the first and second seasons, respectively. 
J. Plant Production, Mansoura Univ., Vol. 3 (9), September, 2012

$\mathrm{T7}$ 
El-Gizawy, N. Kh. B. et al.
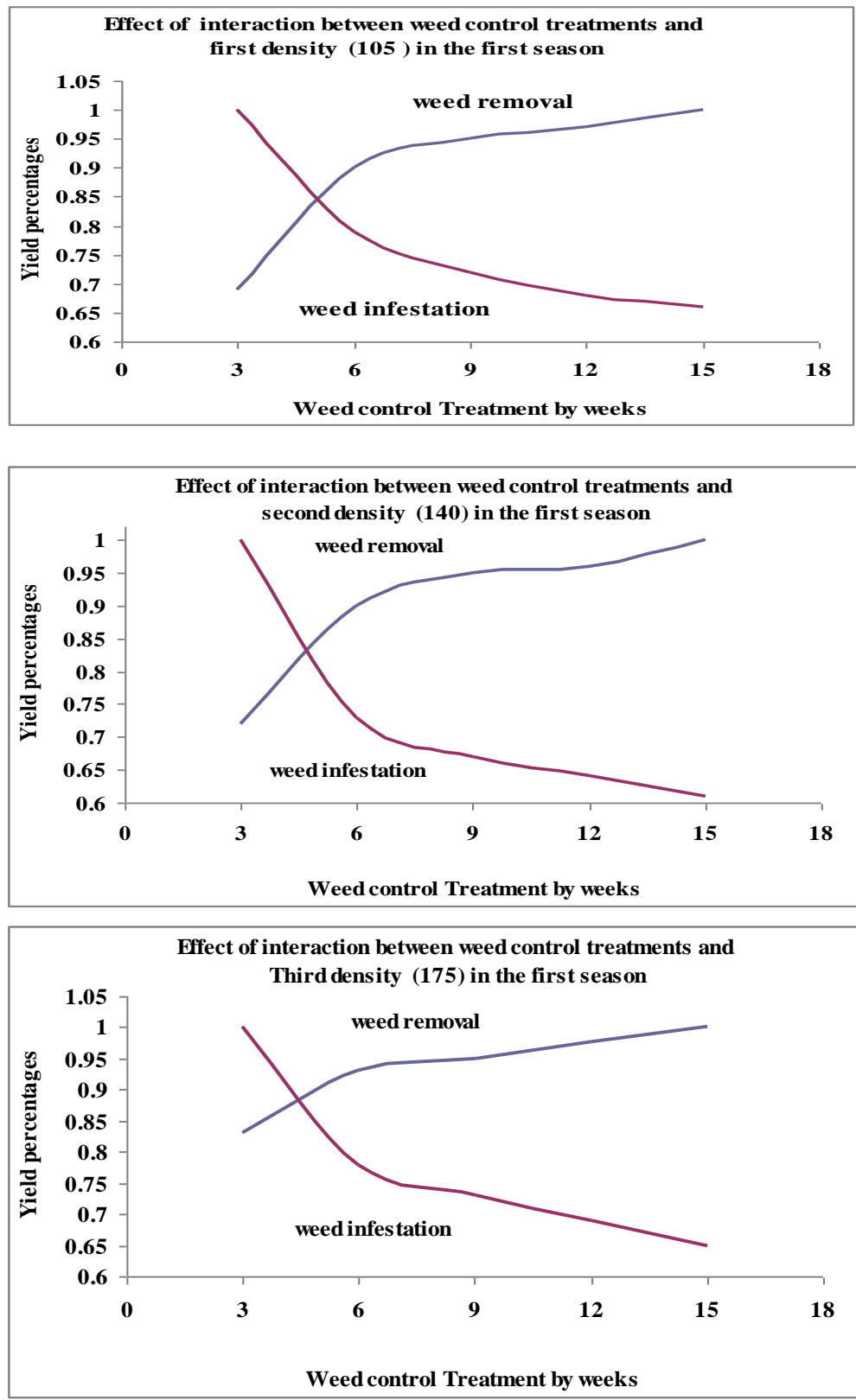

Fig (2): Effect of interaction between weed control treatments and plant density in the first season. 

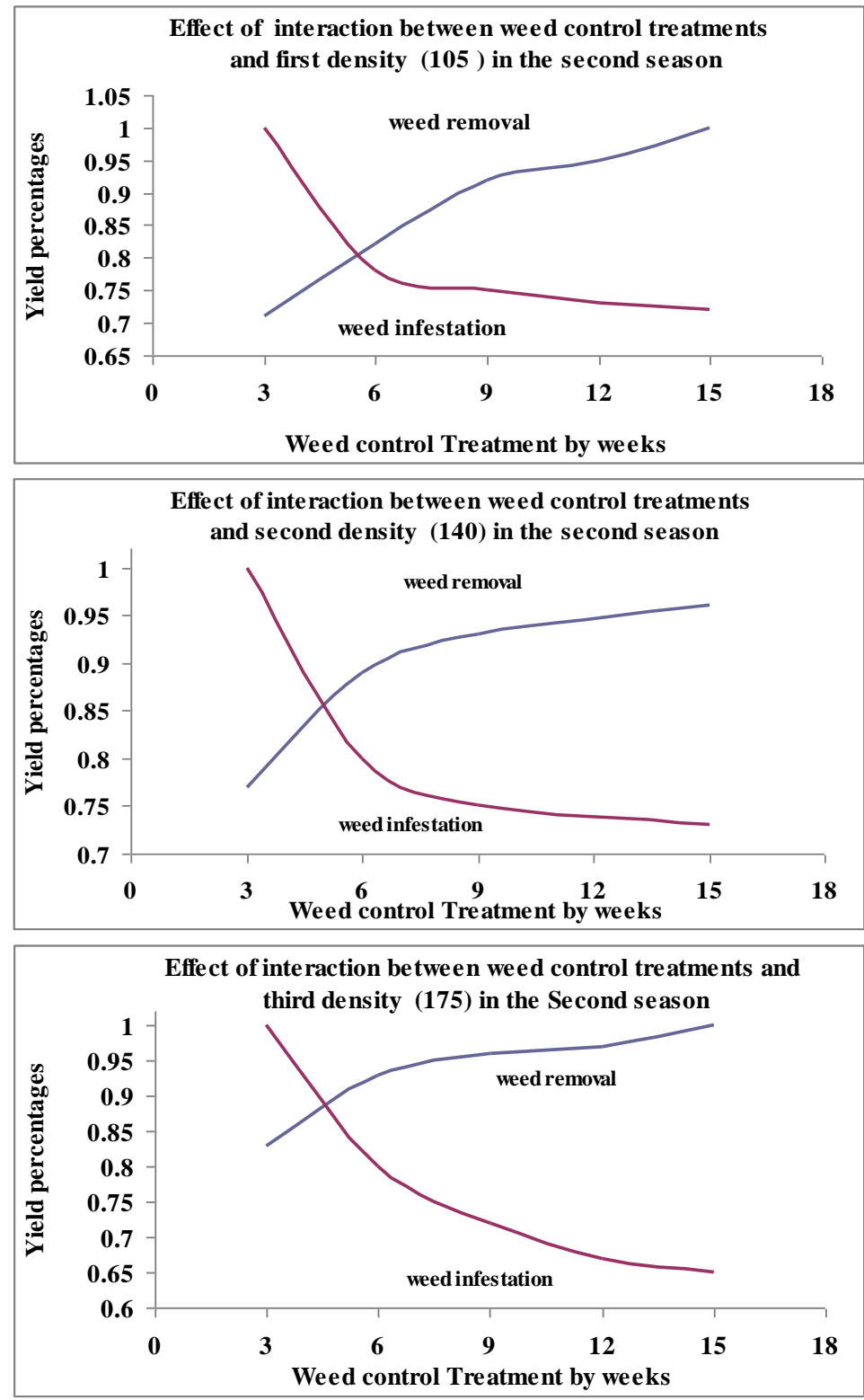

Fig (3): Effect of interaction between weed control treatments and plant density in the second season.

\section{Economic critical period.}

Data in table (8) and Fig (4 \& 5) show that estimates of the threshold of critical period using economic analysis approach depending on the variable costs (LE) which include the costs of land preparation, sowing, fertilization, 


\section{El-Gizawy, N. Kh. B. et al.}

irrigation, insect control, harvesting and rental cost of land and variable cost of hand pulling show that the early weed competition start after 3 weeks from sowing soybean when the total cost were 3150 and 3150 L.E and total income 3080 and 3492.5 LE. meanwhile late economic ended cost at 6 weeks from competition where total cost 3450 and 3450 L.E. and total income 3245 and 3355 L.E in 2009 and 201. Such approach was used by Dunan et al. (1995) and Mekky et al. (1995).

Table (8): Economic evaluation of effect of weed competition soybean in 2009 and 2010 seasons.

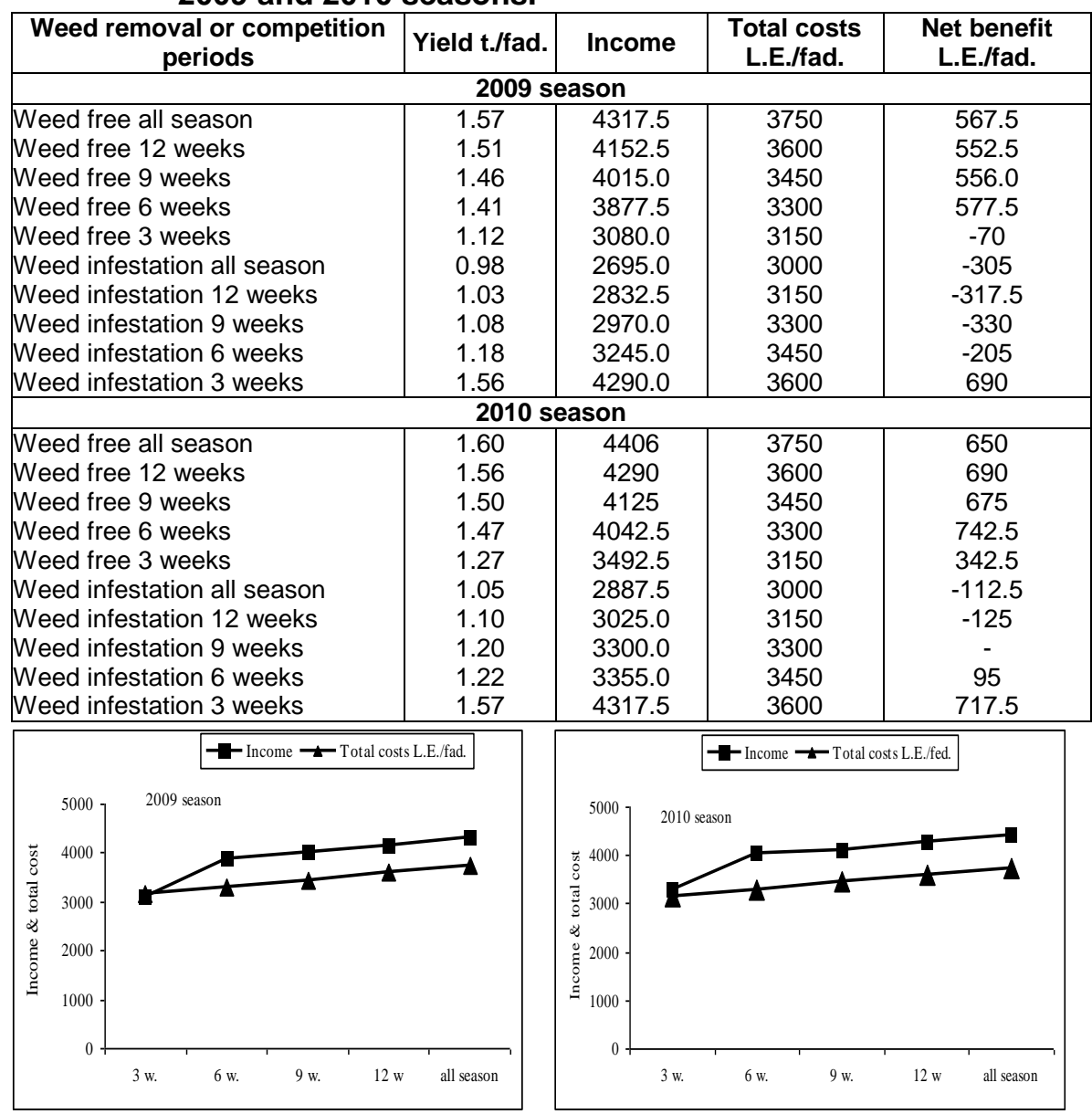

Fig. (4): The relation between income and total cost in weed free period in 2009/2010 seasons. 


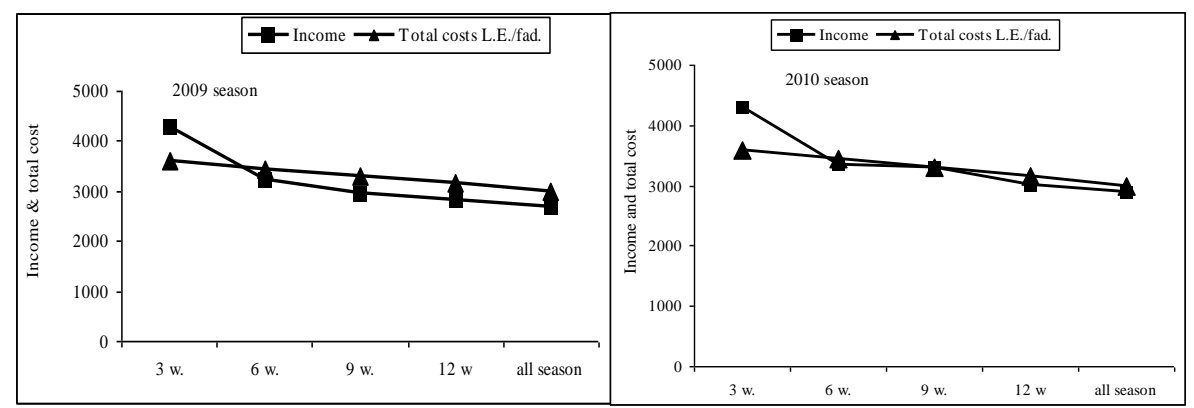

Fig (5): The relation between income and total cost in weed competition period in 2009/2010 seasons.

\section{Correlation between all studied traits and soybean seed yield:}

Data tabulated in table (9) clearly that Correlation between dry weight of total annual weeds and soybean seed yield recorded the highest value. Where it negative affected soybean seed yield by $(-0.660$ and -0.636$)$ at $5 \%$ level in the first and second seasons.

Also, correlation study reveal that the yield increase due to type of weed competition were positively contributed to the increase in the number of branches (0.965), seed weight (0.88), number of seed/pod (0.649) and weight 100 seeds $(0.896)$.

Table (9): Correlation between all studied traits and soybean seed yield:

\begin{tabular}{|c|c|c|c|c|c|c|c|}
\hline Characters & $\begin{array}{l}\text { Total } \\
\text { annul } \\
\text { weed }\end{array}$ & $\begin{array}{l}\text { Plant } \\
\text { length }\end{array}$ & $\begin{array}{l}\text { No. of } \\
\text { branches/ } \\
\text { plant }\end{array}$ & $\begin{array}{c}\text { Seeds } \\
\text { weight } \\
\text { (g.) }\end{array}$ & $\begin{array}{c}\text { No. of } \\
\text { seed/pod }\end{array}$ & $\begin{array}{c}\text { Weight } \\
100 \\
\text { seeds } \\
\text { (g.) }\end{array}$ & $\begin{array}{l}\text { Yield } \\
\text { ton/fad. }\end{array}$ \\
\hline \multicolumn{8}{|c|}{2009} \\
\hline Total annual weed & - & - & - & - & - & - & - \\
\hline Plant length & -0.662 & - & - & - & - & - & - \\
\hline No. & -0.714 & 0.636 & - & - & - & - & - \\
\hline Seeds weight (g.) & -0.649 & 0.682 & 0.923 & - & - & - & - \\
\hline No. of seed/pod & -0.665 & 0.562 & 0.916 & 0.945 & - & - & - \\
\hline Weight 100 seeds & -0.659 & 0.628 & 0.85 & 0.925 & 0.908 & - & - \\
\hline Yield ton/fad. & -0.660 & 0.621 & 0.965 & 0.88 & 0.849 & 0.896 & - \\
\hline \multicolumn{8}{|c|}{2010} \\
\hline Total annual weed & & - & - & - & - & - & - \\
\hline Plant length & -0.684 & - & - & - & - & - & - \\
\hline $\begin{array}{l}\text { No. } \\
\text { branches/plant of }\end{array}$ & -0.627 & 0.560 & - & - & - & - & - \\
\hline Seeds weight (g.) & -0.605 & 0.588 & 0.915 & - & - & - & - \\
\hline No. of seed/pod & -0.741 & 0.657 & 0.851 & 0.777 & - & - & - \\
\hline Weight 100 seeds & -0.655 & 0.663 & 0.84 & 0.906 & 0.851 & - & - \\
\hline Yield ton/fad. & -0.636 & 0.596 & 0.827 & 0.826 & 0.895 & 0.932 & - \\
\hline
\end{tabular}




\section{El-Gizawy, N. Kh. B. et al.}

\section{Conclusion}

According to fit of curve estimate models it could concluded that to obtain the highest seed yield of soybean $(90 \%)$ the critical period of weed control under over three plant densities were 6 weeks for weed-free and 4 weeks for weed competition as average two years. When the plant density increase the critical period was decrease while the critical period increase when the plant density decrease. These results due to inter and intraspsefic soybean plants and soybean plants with weeds

\section{REFERENCES}

Agresti, Alan (1996). An introduction to categorical Data Analysis. John Wiley and Sons, Inc.

A.O.A.C. (1985). "Official methods of analysis, the A.O.A.C. $13^{\text {th }}$ ed., Published by A.O.A.C. Washington, DC 2004, U.S.A.

Chirila, S. and P. Chirila (2008). Research regarding soybean crop critical period to weed harmfulness Lucrari stiiniufica-universitatae de stiinte Agro. Bucuresti. Seria A, Agronomie 51: 507-512.

Dawson, J.H.(1970). Time and duration of weed infestation in relation to weed- crop competition .Proc. South. Weed SC. Soc. 23:13-25.

Dunan, C, M.; E.E. Westra, Sch weizer, D.Ly becker and F.D.Moove(1995). The concept and application of early economic period threshold: The case (Allium cepa). Weed Sci.43:634-639.

Evans, S. P.; S. Z. Knezevic; J. L. (Lindquist; C. A. Shapiro and E. E. Blankenship (2003). Nitrogen application influences the critical period for weed control in corn. Weed Sci. 51: 408-417.

Gomez, K. A. and A. A. Gomez (1984). Statistical procedures for agricultural research . John Wiley \& Sons, Inc. New York, USA.

Hall, M. R.; C. J. Swanton and G. W. Anderson (1992). The critical period of weed control in grain corn (Zea mays). Weed Sci. 40: 441-447.

Keramati, S.; H. Pirdashti; M. A. Esmaili, A. Abbasian and A. Habibi (2008). The critical period of weed control in soybean in north of Iran condition. Pakistan J. of Bio. Sci. 11: 3, 463-467.

Knezevic, S. Z.; S. P. Evans; E. E. Blankenship; R. C. Van Acker and J. L. Lindquist (2002). Critical periods for weed control: the concept and data analysis. Weed Sci. 50: 773-786.

Knezevic, S. Z.; S. P. Evans and M. Mainz (2003). Row spacing influences the critical timing for weed removal in soybean (Glycine max). Weed Tech. 17: 666-673.

Jackson, M. L. (1958). Soil Chemical Analysis. Constable \& Co. Ltd London, England.

Moghadam, Z. H.; M. Paseban and E. Sedigh (2010). Effect of weeding time of velvet leaf on yield and component yield of soybean. Proceedings of biology and ecophysiology, Babolsar, Iran, 17-18 Feb. 2010, 373-378. 9 ref. 
Nagaraju, A. P. and H. K. M. Kumar (2009). Critical period of weed interferance in soybean under alfisols. Mysore J. of Agric. Sci., 43: 1, 28-31.

Neter, J.; W. Wasserman and M. H. Kunter (1990). Applied linear statistical models. $3^{\text {rd }}$ ed., IRWIN, Homewood, Boston, U.S.A.

Norsworthy, J. K. and M. J. Oliverira (2004). Comparison of the critical period for weed control in wide and narrow row corn. Weed Sci. 52: 802-807.

Odeleye, F. O.; O. M. O. Odeleye and O. A. Dada (2007). The performance of soybean cultivars under varying weeding regimes in south western Nigeria. Natulate Botonicae, Horti. Agrobotanici, Cluj-Napoca. 35: 1, 27-36.

Raei, Y.; K. G. Golezani, A. Javanshir, H. Aliari and A. Mohammadi (2008). Effect of plant density on soybean and sorghum. J. of Sci. and Tench. of Agric. and natural Resources. 12: 45 (A), 33-45.

Snedecor, G. and W. G. Cochran (1980). "Statistical Methods"7th ed. lowa State Univ., Ames, lowa, USA.

Sorenson, P. S. (1947). The analysis of foods. Jon. Willey and Sons, New York, U.S.A.

Tanbachnick, B. and L. Fidell (1996). Using Multivariate Statistics, $3^{\text {rd }}$ edition. Harper Collins.

Tripathi, R. D.; P. Srivastava, M. S. Nsra and S. C. Pandey (1971). Protein control in some varieties of leyumes. The Allah Abad Farmer, 16: 291296.

Yaduraju, N.T. and J. S. Mishra (2004). Integrated weed management in soybean. JNKVV Res. J.. Publ. 2005 38: 1, 1-12.

Zimdahl, R. L. (1988). The concept and application of the critical weed free period. In Altieri, M.A \& Liebmann, M., eds. Weed Management in Agroeco system: Ecological Aproaches . PP 145 -155 CRS Press. Boca Roton . Florida ,USA. 
EI-Gizawy, N. Kh. B. et al.

تقدير الفترة الحرجة لمنافسة الحشائش فى محصول فول الصويا تحت تاثير الكثافة النباتية

ناصر خميس بركات الجيزاوى(') أشرف محمد فضل الله (") أحمد مصطفى أحمد حسـانين(")

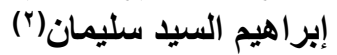

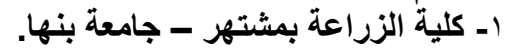

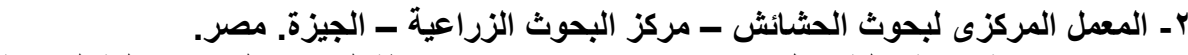

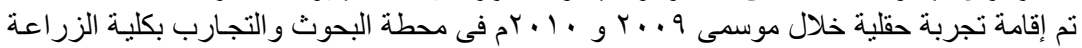

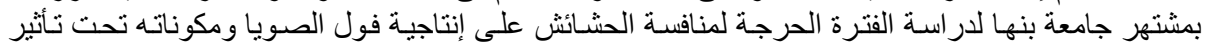

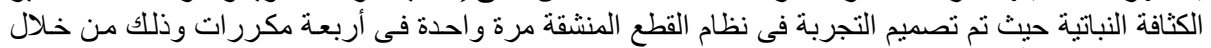

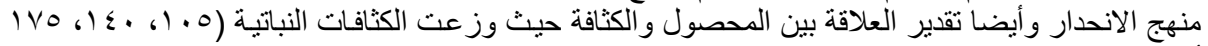

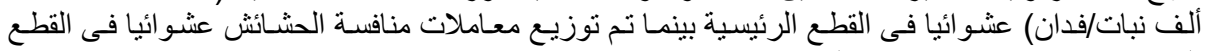
الـنشقة وكانت معاملات منافسة الحشائش هى:-

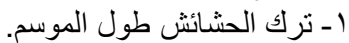

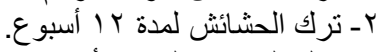

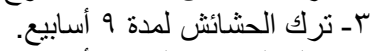

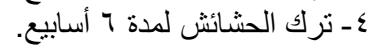

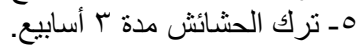

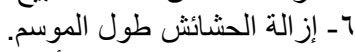

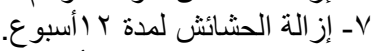

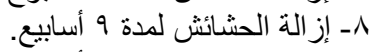

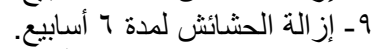

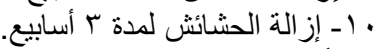

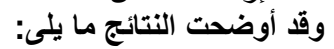

ا ـ أوضحت العاقات الرياضية أن الفقد فى المحصول نتيجة منافسة الحشائش تحت الكثافات النباتئة المختلفة طول

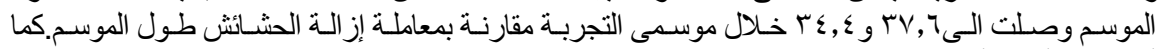

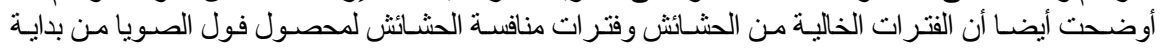

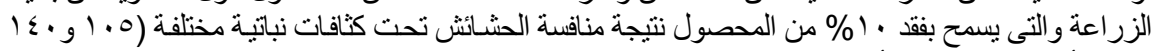

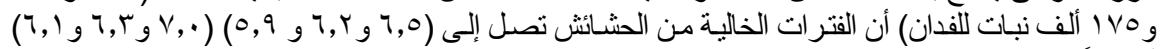

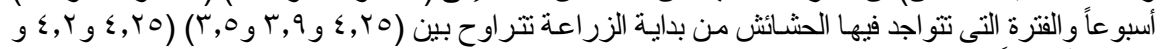

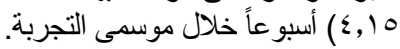

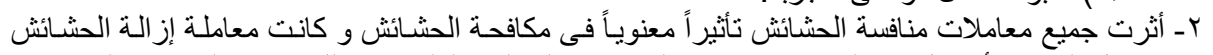

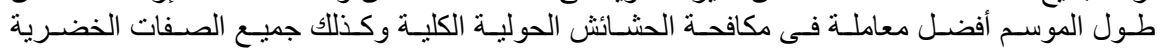
و والمصصول تحت الدراسة خلال موسمى التجربة.

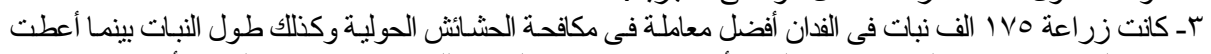

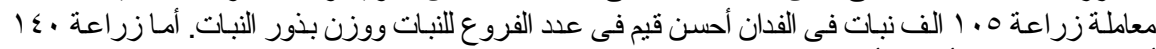

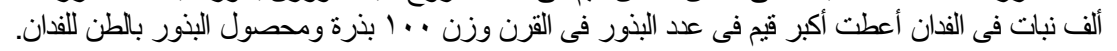

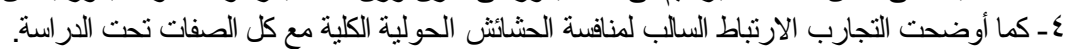

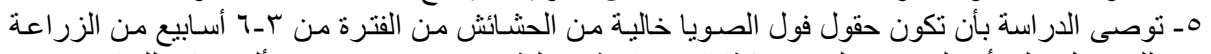

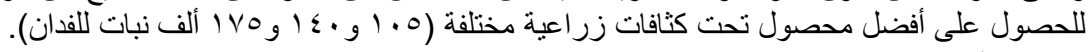

كلية الزراعة - جامعة المنصورة مركز البحوث الزراعية

قام بتحكيم البحث البحث

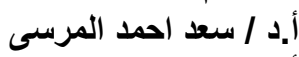
أ.د / ألدسانين الثربينى حسانين العرينى 
J. Plant Production, Mansoura Univ., Vol. 3 (9), September, 2012 
J. Plant Production, Mansoura Univ., Vol. 3 (9): 2375 - 2394, 2012

Table (3): Effect of weed infestation treatments on dry weight of total annual weed, yield and yield component in 2009 and 2010 seasons.

\begin{tabular}{|c|c|c|c|c|c|c|c|c|c|}
\hline $\begin{array}{l}\text { Weed removal or competition } \\
\text { periods }\end{array}$ & Weed $\mathrm{g} / \mathrm{m}^{2}$ & $\begin{array}{c}\text { Plant } \\
\text { length }(\mathrm{cm})\end{array}$ & $\begin{array}{c}\text { No. of } \\
\text { branches/ } \\
\text { plant }\end{array}$ & $\begin{array}{l}\text { Seed weight/ } \\
\text { plant (g) }\end{array}$ & $\begin{array}{c}\text { No. of } \\
\text { seed/pod. }\end{array}$ & $\begin{array}{l}\text { Weight of } \\
100 \text { seed } \\
\text { (g) }\end{array}$ & $\begin{array}{l}\text { Yield t. } \\
\text { /fad. }\end{array}$ & Oil \% & Protein \% \\
\hline & \multicolumn{9}{|c|}{2009 season } \\
\hline Weed free for whole season & $33.74 \mathrm{~h}$ & $112.4 a$ & $2.98 \mathrm{a}$ & $24.05 a$ & $2.82 \mathrm{a}$ & $23.83 a$ & $1.57 \mathrm{a}$ & $22.20 \mathrm{a}$ & $39.00 \mathrm{a}$ \\
\hline Weed free 12 weeks & $40.97 \mathrm{~g}$ & $106.2 \mathrm{~b}$ & $2.68 \mathrm{c}$ & $21.82 \mathrm{~b}$ & $2.70 \mathrm{~b}$ & $20.50 \mathrm{c}$ & $1.51 \mathrm{c}$ & $21.80 \mathrm{a}$ & $38.80 \mathrm{a}$ \\
\hline Weed free 9 weeks & $79.15 d$ & $94.47 d$ & $2.60 \mathrm{~d}$ & $18.25 \mathrm{e}$ & $2.57 \mathrm{c}$ & $19.00 \mathrm{~d}$ & $1.46 \mathrm{~d}$ & $23.00 \mathrm{a}$ & $38.80 \mathrm{a}$ \\
\hline Weed free 6 weeks & $235.9 \mathrm{c}$ & $90.17 \mathrm{e}$ & $2.23 f$ & $15.12 f$ & $2.46 \mathrm{~d}$ & $17.67 \mathrm{e}$ & $1.41 \mathrm{e}$ & $22.40 \mathrm{a}$ & $38.85 a$ \\
\hline Weed free 3 weeks & $320.1 b$ & $85.53 f$ & $1.88 \mathrm{~h}$ & $12.93 \mathrm{~g}$ & $2.20 f$ & $16.00 f$ & $1.12 \mathrm{~g}$ & $23.60 \mathrm{a}$ & $38.62 a$ \\
\hline Weed infestation for whole season & $579.3 a$ & $83.03 \mathrm{~g}$ & $1.77 \mathrm{i}$ & $10.32 \mathrm{i}$ & $2.10 \mathrm{~g}$ & $10.00 \mathrm{~h}$ & $0.98 \mathrm{j}$ & $21.60 \mathrm{a}$ & $38.77 a$ \\
\hline Weed infestation 12 weeks & $52.68 \mathrm{e}$ & $89.25 \mathrm{e}$ & $2.02 \mathrm{~g}$ & $12.05 \mathrm{~h}$ & $2.20 f$ & $13.67 \mathrm{~g}$ & $1.03 \mathrm{i}$ & $22.50 \mathrm{a}$ & $38.72 \mathrm{a}$ \\
\hline Weed infestation 9 weeks & $49.98 \mathrm{ef}$ & $95.56 \mathrm{~d}$ & $2.48 \mathrm{e}$ & $14.98 f$ & $2.40 \mathrm{e}$ & $16.00 \mathrm{f}$ & $1.08 \mathrm{~h}$ & $22.00 \mathrm{a}$ & $38.84 a$ \\
\hline Weed infestation 6 weeks & 47.06ef & $102.2 \mathrm{c}$ & $2.83 \mathrm{~b}$ & $18.70 \mathrm{~d}$ & $2.60 \mathrm{c}$ & $17.67 \mathrm{e}$ & $1.18 \mathrm{f}$ & $23.90 \mathrm{a}$ & $38.68 \mathrm{a}$ \\
\hline \multirow[t]{2}{*}{ Weed infestation 3 weeks } & $45.67 \mathrm{fg}$ & $106.6 \mathrm{~b}$ & $2.97 a$ & $20.75 c$ & $2.72 b$ & $22.50 \mathrm{~b}$ & $1.56 \mathrm{~b}$ & $22.80 \mathrm{a}$ & $38.67 a$ \\
\hline & \multicolumn{9}{|c|}{ 2010season } \\
\hline Weed free for whole season & $32.61 \mathrm{~g}$ & $114.4 a$ & $3.10 \mathrm{a}$ & $27.70 \mathrm{a}$ & $2.90 \mathrm{ab}$ & $27.11 \mathrm{a}$ & $1.60 \mathrm{a}$ & 21.40 & $38.60 \mathrm{a}$ \\
\hline Weed free 12 weeks & $37.8 \mathrm{i}$ & $108.2 \mathrm{~b}$ & $2.70 \mathrm{~b}$ & $24.40 \mathrm{~b}$ & $2.70 \mathrm{c}$ & $25.11 \mathrm{~b}$ & $1.56 \mathrm{c}$ & $22.60 \mathrm{a}$ & $38.88 \mathrm{a}$ \\
\hline Weed free 9 weeks & $73.51 d$ & $96.8 \mathrm{e}$ & $2.60 \mathrm{c}$ & $21.20 \mathrm{c}$ & $2.60 d$ & $21.44 d$ & $1.50 \mathrm{~d}$ & $22.80 \mathrm{a}$ & $39.18 \mathrm{a}$ \\
\hline Weed free 6 weeks & $213.7 \mathrm{c}$ & $91.7 f$ & $2.20 \mathrm{e}$ & $17.70 \mathrm{e}$ & $2.50 \mathrm{e}$ & $19.44 \mathrm{e}$ & $1.47 \mathrm{e}$ & $23.70 \mathrm{a}$ & $38.37 a$ \\
\hline Weed free 3 weeks & $307.3 b$ & $89.4 \mathrm{~g}$ & $2.10 f$ & $14.20 \mathrm{~g}$ & $2.40 \mathrm{f}$ & $18.33 f$ & $1.27 f$ & $23.50 \mathrm{a}$ & $39.20 \mathrm{a}$ \\
\hline Weed infestation for whole season & $565.5 \mathrm{a}$ & $83.5 \mathrm{~h}$ & $1.80 \mathrm{~g}$ & $11.50 \mathrm{i}$ & $2.10 \mathrm{~g}$ & $12.56 \mathrm{~h}$ & $1.05 \mathrm{j}$ & $23.20 \mathrm{a}$ & $38.90 \mathrm{a}$ \\
\hline Weed infestation 12 weeks & $49.56 \mathrm{e}$ & $92.1 f$ & $2.10 f$ & $13.60 \mathrm{~h}$ & $2.40 f$ & $15.67 \mathrm{~g}$ & $1.10 \mathrm{i}$ & $21.60 \mathrm{a}$ & $38.85 a$ \\
\hline Weed infestation 9 weeks & $46.58 f$ & $100.5 d$ & $2.50 \mathrm{~d}$ & $15.00 f$ & $2.70 \mathrm{c}$ & $18.33 \mathrm{f}$ & $1.20 \mathrm{~h}$ & $21.80 \mathrm{a}$ & $38.83 a$ \\
\hline Weed infestation 6 weeks & $44.44 \mathrm{~g}$ & $104.0 \mathrm{c}$ & $2.80 \mathrm{~b}$ & $20.40 \mathrm{~d}$ & $2.80 \mathrm{~b}$ & $21.11 \mathrm{~d}$ & $1.22 \mathrm{~g}$ & $23.10 \mathrm{a}$ & $38.53 a$ \\
\hline Weed infestation 3 weeks & $40.94 \mathrm{~h}$ & $108.4 \mathrm{~b}$ & $3.00 \mathrm{a}$ & $24.70 \mathrm{~b}$ & $2.90 \mathrm{a}$ & $24.22 \mathrm{c}$ & $1.57 \mathrm{~b}$ & $22.60 a$ & $38.70 \mathrm{a}$ \\
\hline
\end{tabular}




\section{J. Plant Production, Mansoura Univ., Vol. 3 (9), September, 2012}

Table (7): Parameters of three models that were studied on the effect of weed control treatments and plant density on soybean seed yield in 2009 and 2010 seasons.

\begin{tabular}{|c|c|c|c|c|c|c|c|c|}
\hline Season & Treatments & Density & Methods & $\mathbf{R 2}$ & S. E. & Sig. & prediction equation & $\begin{array}{l}\text { CPWC/ week allowed } \\
\text { losing yield (10\%) }\end{array}$ \\
\hline \multirow{18}{*}{$\begin{array}{l}2009 \\
\text { season }\end{array}$} & \multirow{9}{*}{ Weed-free } & \multirow{3}{*}{105} & Linear & 0.747 & 0.106 & 0.059 & $Y=1.066+0.333 x$ & \\
\hline & & & Logistic & 0.899 & 0.067 & 0.014 & $\mathrm{Y}=\ln (0.804)+\ln (0.273) \mathrm{x}$ & \\
\hline & & & Quadratic & 0.914 & 0.076 & 0.086 & $Y=0.786+0.113 \times 1-0.004 \times 2$ & 6.5 \\
\hline & & \multirow{3}{*}{140} & Linear & 0.811 & 0.095 & 0.037 & $Y=1.276+0.036 x$ & \\
\hline & & & Logistic & 0.939 & 0.054 & 0.006 & $Y=\ln (1.005)+\ln (0.289) x$ & 6.2 \\
\hline & & & Quadratic & 0.935 & 0.068 & 0.065 & $Y=1.026+0.107 \times 1-0.004 \times 2$ & \\
\hline & & \multirow{3}{*}{175} & Linear & 0.973 & 0.029 & 0.002 & $\mathrm{Y}=0.964+0.032 \mathrm{x}$ & \\
\hline & & & Logistic & 0.994 & 0.013 & 0 & $Y=\ln (0.756)+\ln (0.241) x$ & 5.9 \\
\hline & & & Quadratic & 0.998 & 0.01 & 0.002 & $Y=0.874+0.058 \times 1-0.001 \times 2$ & \\
\hline & \multirow{9}{*}{$\begin{array}{l}\text { Weed } \\
\text { competition }\end{array}$} & \multirow{3}{*}{105} & Linear & 0.827 & 0.1 & 0.032 & $Y=0.809+0.04 x$ & \\
\hline & & & Logistic & 0.647 & 0.142 & 0.101 & $Y=\ln (0.628)+\ln (0.262) x$ & \\
\hline & & & Quadratic & 0.982 & 0.04 & 0.018 & $\mathrm{Y}=1.114-0.0475 \times 1+0.005 \times 2$ & 4.25 \\
\hline & & \multirow{3}{*}{140} & Linear & 0.765 & 0.147 & 0.052 & $Y=0.815+0.0483 x$ & \\
\hline & & & Logistic & 0.586 & 0.195 & 0.131 & $\mathrm{Y}=\ln (0.600)+\ln (0.315) \mathrm{x}$ & \\
\hline & & & Quadratic & 0.952 & 0.081 & 0.048 & $Y=1.24-0.073 \times 1+0.007 \times 2$ & 3.9 \\
\hline & & \multirow{3}{*}{175} & Linear & 0.831 & 0.088 & 0.031 & $Y=0.7390 .036 x$ & \\
\hline & & & Logistic & 0.664 & 0.124 & 0.093 & $Y=\ln (0.571)+\ln (0.238) x$ & \\
\hline & & & Quadratic & 0.966 & 0.049 & 0.034 & $Y=0.994-0.0372 \times 1+0.004 \times 2$ & 3.5 \\
\hline \multirow{18}{*}{$\begin{array}{l}2010 \\
\text { season }\end{array}$} & \multirow{9}{*}{ Weed-free } & \multirow{3}{*}{105} & Linear & 0.838 & 0.059 & 0.029 & $Y=1.241+0.024 x$ & \\
\hline & & & Logistic & 0.959 & 0.029 & 0.004 & $Y=\ln (1.06)+\ln (0.194) x$ & \\
\hline & & & Quadratic & 0.96 & 0.036 & 0.04 & $Y=1.076+0.071 \times 1-0.003 \times 2$ & 7 \\
\hline & & \multirow{3}{*}{140} & Linear & 0.902 & 0.055 & 0.013 & $Y=1.317+0.03 x$ & \\
\hline & & & Logistic & 0.971 & 0.03 & 0.002 & $\mathrm{Y}=\ln (1.107)+\ln (0.235) \mathrm{x}$ & 6.3 \\
\hline & & & Quadratic & 0.951 & 0.048 & 0.049 & $Y=1.192+0.066 \times 1-0.002 \times 2$ & \\
\hline & & \multirow{3}{*}{175} & Linear & 0.86 & 0.042 & 0.023 & $Y=1.22+0.019 x$ & \\
\hline & & & Logistic & 0.968 & 0.02 & 0.003 & $Y=\ln (1.08)+\ln (0.15) x$ & 6.1 \\
\hline & & & Quadratic & 0.959 & 0.028 & 0.041 & $Y=1.104+0.052 x-0.002 \times 2$ & \\
\hline & \multirow{9}{*}{$\begin{array}{l}\text { Weed } \\
\text { competition }\end{array}$} & \multirow{3}{*}{105} & Linear & 0.695 & 0.128 & 0.079 & $\mathrm{Y}=0.82+0.035 \mathrm{x}$ & \\
\hline & & & Logistic & 0.519 & 0.161 & 0.17 & $\mathrm{Y}=\ln (0.669)+\ln (0.228) \mathrm{x}$ & \\
\hline & & & Quadratic & 0.911 & 0.085 & 0.089 & $Y=1.17-0.065 \times 1+0.006 \times 2$ & 4.25 \\
\hline & & \multirow{3}{*}{140} & Linear & 0.826 & 0.103 & 0.033 & $\mathrm{Y}=1.023+0.41 \mathrm{x}$ & \\
\hline & & & Logistic & 0.668 & 0.142 & 0.091 & $Y=\ln (0.826)+\ln (0.275) x$ & \\
\hline & & & Quadratic & 0.953 & 0.066 & 0.047 & $Y=1.31-0.0404 \times 1+0.005 \times 2$ & 4.2 \\
\hline & & \multirow{3}{*}{175} & Linear & 0.858 & 0.087 & 0.024 & $Y=0.776+0.039 x$ & \\
\hline & & & Logistic & 0.702 & 0.127 & 0.077 & $Y=\ln (0.584)+\ln (0.265) x$ & \\
\hline & & & Quadratic & 0.96 & 0.057 & 0.04 & $Y=1.016-0.029 x+0.004 x 2$ & 4.15 \\
\hline
\end{tabular}

- 2397 - 
El-Gizawy, N. Kh. B. et al.

- 2398 - 